Крім вдосконалення іншомовної комунікативної компетентності та поглиблення знань з історії нашої країни, інтеграція вивчення англійської мови та історії України характеризується своєю направленістю на становлення особистості учнів старшої школи, їх духовний розвиток, усвідомлення власної національно-культурної ідентичності. Іноземна мова стає засобом висловлення про об'єктивну дійсність, закономірності якої є предметом інших дисциплін. Крім того, результати опитування вказують, що 16,9\% школярів готові були обрати інтегративний елективний курс «Історія України англійською мовою» для вивчення, а 21,1\% респондентів не були готові дати чітку відповідь, отже, потенційно також можуть бути зацікавлені у його вивченні. Отже, запровадження інтегративного елективного курсу «Історія України англійською мовою» у старшій школі $є$ актуальним на даному етапі, оскільки відповідає потребам учнів старшої школи, сприяє їхньому особистому розвитку та надає широкий вибір майбутньої спеціалізації.

\title{
Література:
}

1. Бим И. Л. Профильное обучение иностранным языкам на старшей ступени общеобразовательной школы. Проблемы и перспективы. Москва, 2007. $211 \mathrm{c}$.

2. Зеня Л. Я. Навчання іноземних мов у старшій профільній школі: лекційно- практичний курс: посіб. для студ. вищ. навч. закладів. Горлівка, 2008. 340 с.

3. Сажко Л. А. Інтегративна основа навчання іноземних мов. URL : http://www. irbis-nbuv. gov. ua/cgi-bin/irbis_nbuv (дата звернення: 19.02.2021)

DOI https://doi.org/10.30525/978-9934-26-039-1-102

\section{ВНУТРІШНЯ МОТИВАЦІЯ ЯК ЗАПОРУКА УСПІШНОГО Й ЕФЕКТИВНОГО ВИВЧЕННЯ ІНОЗЕМНИХ МОВ}

\author{
Швечкова Ю. О. \\ викладач служби мовної підготовки мовного відділу \\ Начіональної академії Національної гвардї̈ України \\ м. Харків, Украӥна
}

Сьогодні ми живемо у світі, який неможливо уявити без міжнародної співпраці та, відповідно, без знання іноземних мов як одного зі способів можливості іï реалізації. Крім того, володіння ними дозволяє нам вільно 172 
подорожувати й спілкуватися 3 мешканцями інших держав без жодних комунікативних проблем. Іншими словами, вивчення іноземних мов кожною сучасною людиною залишається питанням надзвичайно важливим та актуальним. Проте досягнути високих результатів у цій справі, не маючи при цьому певного внутрішнього прагнення, бажання або поштовху, майже неможливо. Саме тому безумовною запорукою успішного й ефективного вивчення іноземних мов $€$ наявність у того, хто їх вивчає, внутрішньої мотивації.

Перш ніж ми з'ясуємо, що означає це поняття, пропонуємо визначити, що таке мотивація взагалі.

У великому тлумачному словнику сучасної української мови надається три дефініції цього терміну, одна з яких така: «мотивація - це заохочення учнів до вивчення певного предмета, дисципліни, пояснення необхідності навчання в школі» [1, с. 692]. На нашу думку, це визначення $\epsilon$ дуже доречним і влучним, тому в нашій роботі ми спираємося саме на нього.

Відомі дослідники Е. Десі та Р. Райан виділяють два типи мотивації:

1) внутрішню мотивацію;

2) зовнішню мотивацію;

Внутрішня мотивація визначається як здійснення діяльності заради власного задоволення, а не заради окремого наслідку. Коли людина внутрішньо мотивована, вона спонукувана діяти заради веселощів або поставленої задачі, а не через зовнішні мотиви, тиск або нагороди $[5$, c. 56$]$.

Зовнішня мотивація - це конструкт, властивий діяльності, що виконується 3 метою досягнення окремого результату [5, с. 60].

Таким чином, ми бачимо, що внутрішня та зовнішня мотивації $€$ практично протилежними поняттями: коли людина виконує певні дії з метою отримання власного внутрішнього задоволення, насолоди, приємних емоцій, тобто радіє від самого процесу, це свідчить про те, що нею керує внутрішня мотивація; коли вона займається певною діяльністю лише задля отримання якихось зовнішніх переваг, а не заради насолоди самим процесом, то це свідчить про зовнішню мотивацію.

Порівнявши ці два типи мотивації, ми вважаємо, що ефективність першого типу буде значно вищою, адже саме внутрішня мотивація може гарантувати найкращі результати в будь-якій справі, у тому числі у вивченні іноземних мов. Внутрішньо мотивований студент, на відміну від зовнішньо мотивованого одногрупника, працюватиме сумлінно та старанно завжди, а не лише якийсь період часу, поки не буде отримана певна зовнішня нагорода. 3 нашої точки зору, викладач має завжди 
пам'ятати про важливість саме внутрішньої мотивації та сприяти iï активізації.

На основі власного досвіду ми можемо запропонувати такі шляхи підвищення внутрішньої мотивації:

\section{1. Проведення занять на основі відеоматеріалів.}

Це можуть бути як фрагменти популярних фільмів або серіалів іноземною мовою, що вивчається, так i, наприклад, інтерв'ю з відомими людьми. Така робота викликає безумовне зацікавлення у студентів, адже в них з'являється можливість спробувати самостійно зрозуміти, про що говорить улюблений кіногерой або співак, поринути у світ носіїв мови.

\section{2. Проведення занять на основі аудіоматеріалів.}

Це може бути, наприклад, фрагмент радіопередачі або іншомовна пісня. Звичайно, кожен викладач іноземної мови знає, що з навчанням на основі пісень варто бути надзвичайно обережним, оскільки в сучасних музичних творах вживається багато сленгу, скорочених форм слів або навіть граматично неправильних конструкцій, тому їх вибір має бути дуже ретельним. Проте працюючи з улюбленими піснями, учні завжди отримують велике задоволення й працюють надзвичайно активно.

3. Проведення занять на основі художньої літератури або журнальних статей, написаних іноземною мовою як мовою оригіналу.

Читання іноземної художньої літератури або статей з журналів - це окремий цікавий спосіб занурення студентів у культуру носіїв мови. Особливий інтерес в них викликає робота не просто з роздруківками, а саме зі справжніми книгами або журналами. Крім того, як ми встигли помітити, учні сприймають це як більш серйозний рівень, ніж роботу зі звичайними текстами з підручників, а тому дуже пишаються собою, коли в них з'являється розуміння сюжету.

\section{4. Впровадження під час занять мовних ігор.}

Як показує наш досвід, цей спосіб підвищення внутрішньої мотивації учні, напевно, люблять більше за все. Наприклад, їм зазвичай дуже подобається гра «Who am I?» (тут і далі наводяться приклади назв ігор i тем занять англійською мовою) з використанням фотокарток відомих людей (iї особливо доречно впроваджувати, проводячи заняття за темою «Appearance»). Також, вони люблять рольові ігри, які можна реалізовувати у межах дуже багатьох тем: вивчаючи тему «Shopping» можна «приміряти» на себе ролі продавця та покупця, «Crimes» злочинця та слідчого тощо. Завдяки мовним іграм студенти з легкістю запам'ятовують нову лексику та відпрацьовують граматичні конструкції; крім цього, завдяки власне рольовим іграм відразу бачать, як би це 
виглядало у реальному житті, тобто розуміють, для чого їм необхідні певні теми.

\section{5. Виконання під час занять творчих завдань.}

Такі завдання дозволяють викликати інтерес до заняття навіть в тих осіб, кому іноземна мова поки що дається важко, адже протягом виконання таких вправ учням можуть стати в пригоді доволі різні творчі здібності, які, на перший погляд, ніяк не пов'язані з іноземною мовою: малювання, спів, акторські таланти, написання віршів тощо. Наприклад, працюючи 3 темою «The house of my dream», викладач може запропонувати не просто описати будинок своєї мрії, а й попередньо його намалювати.

Безумовно, обираючи той чи інший шлях підвищення внутрішньої мотивації на певному занятті, варто обов'язково враховувати його тему, навчальні питання та рівень групи; можливо, будувати на основі цього шляху не цілий урок, а лише якийсь його фрагмент.

На нашу думку та як показує наша практика, при ретельно продуманих діях викладача та правильно застосованих ним методах навчання, запропоновані нами шляхи підвищення внутрішньої мотивації викликають у студентів зацікавленість, сприяють активізації їхньої пізнавальної діяльності, призводять до розуміння того, що вивчення іноземної мови - це не лише робота з підручниками та постійне вивчення безлічі нових слів, а й активна та весела справа, яка дозволяє дізнатися багато чого нового не лише у межах власне іноземної мови, а й взагалі загального розвитку, а також проявити свої творчі здібності, що, відповідно, призводить до кращої та більш продуктивної роботи. I головне, учні починають отримувати задоволення від самого процесу навчання, що відповідно позитивно позначається і на його результатах.

\section{Література:}

1. Великий тлумачний словник сучасної української мови (з дод. i допов.) / Уклад. і голов. ред. В. Т. Бусел. Київ : Ірпінь; ВТФ «Перун», 2005. $1728 \mathrm{c}$.

2. Знанецька О. М. Проблеми мотивації навчання іноземної мови у вищій школі. Вісник Запорізького національного університету. Педагогічні науки. 2012. № 2(18). С. 87-92.

3. Луценко О. В. Мотивація як основа свідомого ставлення здобувачів вищої освіти до навчальної діяльності. Вісник Житомирського державного університету імені Івана Франка. Педагогічні науки. 2016. № 2(84). С. 71-77. 
4. Швечкова Ю. О., Бездітко А. Р. Мотивація курсантів нефілологічного напрямку підготовки до вивчення іноземних мов. Методика та специфіка викладання іноземних мов у закладах вищої освіти: тези доповідей всеукраїнської науково-методичної конференції (Харків, 7 грудня 2020 р.). Харків: Національна академія Національної гвардї України, 2020. С. 92-94.

5. Deci E., Ryan R. Intrinsic and Extrinsic Motivations: Classic Definitions and New Directions. Contemporary Educational Psychology. 2000. № 25. P. 54-67.

DOI https://doi.org/10.30525/978-9934-26-039-1-103

\title{
ТРИЛІНГВІЗМ У ПРОЦЕСІ НАВЧАННЯ ГРАМАТИКИ АНГЛІЙСЬКОЇ МОВИ
}

\author{
Шепітчак В. А. \\ кандидат педагогічних наук, \\ викладач кафедри англійської філологї \\ та методики навчання англійської мови \\ Тернопільського національного педагогічного університету \\ імені Володимира Гнатюка \\ м. Тернопіль, Украӥна
}

Методика навчання IM2 тісно пов'язана 3 таким лінгвістичним явищем, як трилінгвізм. М. Баришніков і М. Бодоньї визначають його як співіснування трьох мов у мовленнєво-мисленнєвій сфері індивіда, що використовує їх у різних комунікативних цілях відповідно до мети спілкування [1, с. 30]. А. Щепілова стверджує, що трилінгвізм дає можливість для постійного порівняння, зіставлення (свідомого i несвідомого) засобів висловлювання думки різними мовами. Володіння студентами механізмами РМ та німецької мови як першої іноземної мови пов'язано 3 такими процесами, як мислення, пам'ять, лінгвістичний досвід, що є основою для мисленнєво-мовленнєвої діяльності людини [13, с. 17]. Аналіз досліджень з питання багатомовності (А. Карлінський, Б. Маруневич, Н. Мечковська, В. Розенцвейг, Т. Руднєва, Е. Хауген, Л. Щерба й ін.) дає змогу визначити два основні підходи до вивчення IM2: лінгвістичний і психолінгвістичний [7].

Основною причиною виникнення помилок дослідники вважать несумісність у лінгвістичних системах трьох мов, коли системи трьох 176 